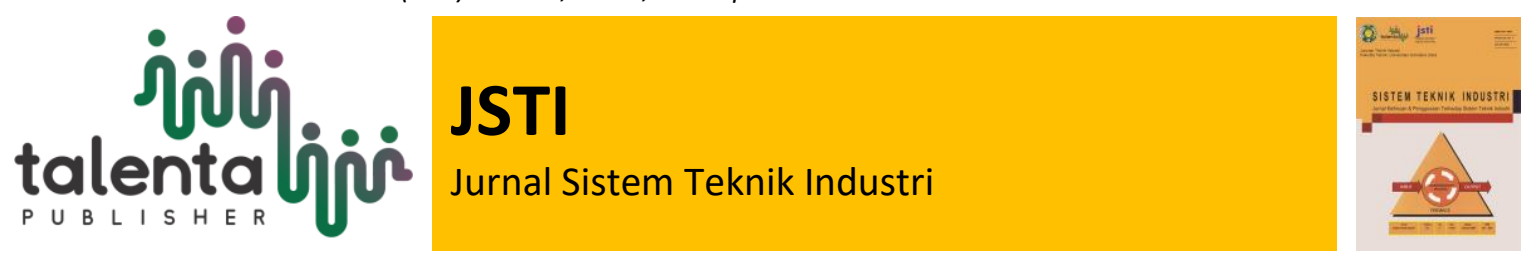

\title{
Quality Function Deployment in Healthcare: Systematic Literature Review
}

\author{
Dias Irawati Sukma ${ }^{1}$ Indra Setiawan ${ }^{2}$, Hibarkah Kurnia ${ }^{3}$, Welly Atikno ${ }^{4}$, \\ Humiras Hardi Purba ${ }^{5}$ \\ 1,2,3,4,5 Master of Industrial Engineering Program, Universitas Mercu Buana, Jakarta, Indonesia \\ Jl. Meruya Selatan No. 1 Kembangan Jakarta
}

\begin{abstract}
More specific knowledge about Quality Function Deployment (QFD) has grown rapidly. There is a lot of research on the application of QFD in various industrial sectors including manufacturing, construction and services. However, it is still found at least the implementation of QFD in health services. This paper aims to provide a broad understanding and knowledge of the application of QFD in the healthcare industry. This paper also informs that QFD is a method that is not yet popular to be applied in the service industry, including health services. The approach used is Systematic Literature Review. This paper involves a review study of various papers from well-known databases related to the implementation of QFD in the healthcare industry. The results showed that QFD can improve service and create customer satisfaction. QFD is a tool that can be used to assist companies in improving services by translating consumer desires into the company's technical characteristics. QFD applications are also often integrated with other approaches so that QFD can be said as a complementary method that is able to provide maximum results. This paper provides benefits for practitioners to increase knowledge and references to improve company performance related to QFD applications in health services.
\end{abstract}

Keyword: Healthcare, House of Quality, Quality Function Deployment, Literature Review

\begin{abstract}
Abstrak. Pengetahuan yang lebih spesifik tentang Quality Function Deployment (QFD) telah berkembang pesat. Terdapat banyak penelitian tentang penerapan QFD di berbagai sektor industri termasuk manufaktur, konstruksi dan jasa. Namun, masih ditemukan sedikitnya penerapan QFD di pelayanan kesehatan. Makalah ini bertujuan untuk memberikan pemahaman dan pengetahuan yang luas tentang penerapan QFD di industri kesehatan. Makalah ini juga menginformasikan bahwa QFD merupakan metode yang belum populer untuk diaplikasikan di industri jasa termasuk pelayanan kesehatan. Pendekatan yang digunakan adalah Systematic Literature Review. Makalah ini melibatkan studi tinjauan berbagai makalah dari database terkenal yang terkait dengan penerapan QFD di industri pelayanan kesehatan. Hasil penelitian menunjukkan, QFD dapat meningkatkan pelayanan dan menciptakan kepuasan pelanggan. QFD merupakan alat yang dapat digunakan untuk membantu perusahaan dalam meningkatkan pelayanan dengan menerjemahkan keinginan konsumen ke dalam karakteristik teknis perusahaan. Aplikasi QFD juga sering diintegrasikan dengan pendekatan lain sehingga QFD dapat dikatakan sebagai metode pelengkap yang mampu memberikan hasil yang maksimal. Makalah ini memberikan keuntungan bagi praktisi untuk menambah pengetahuan dan referensi untuk meningkatkan kinerja perusahaan terkait aplikasi QFD dalam pelayanan kesehatan.
\end{abstract}

Kata Kunci: Healthcare, House of Quality, Quality Function Deployment, Literature Review

Received 04 October 2021 | Revised 22 December 2021 | Accepted 12 January 2022

*Corresponding author at: Meruya Selatan Street No. 1, Kembangan, Jakarta 11650

E-mail address: indra.setiawan.2022@gmail.com

https://doi.org/10.32734/jsti.v24i1.7297 Attribution-NonCommercial-ShareAlike 4.0 International.License Some rights reserved Copyright (C 2022 Published by Talenta Publisher, ISSN: 1411-5247 e-ISSN: 2527-9408

Journal Homepage: http://talenta.usu.ac.id/jsti 


\section{Introduction}

In this era of globalization, all industries must be able to compete in the global market to remain competitive. The intense global market has driven all industries to continuously improve their competitiveness. Among all industrial sectors, the service industry is one of the most decisive industries in increasing the economy and national income. The most important and challenging primary goal of service organizations is to provide high-quality services. The measurement of the main indicators as improving performance is a must to define and measure service quality. One of the main steps in developing this measurement tool is to identify the company's performance and consumer expectations. Service experts agree that service quality results from a comparison between performance and customer expectations. Meeting customer needs can provide a high level of achievement of satisfaction. Therefore, it is very important to understand the difference between customer expectations and service perception.

In the service industry, providing high-quality services is the most important thing and needs attention for all types of service providers because service quality can increase customer satisfaction and have an impact on their good name. Therefore, companies and organizations from various service industries consider service quality improvement as the key to gain market profits and achieve success. One sector of the service industry is health services. Health services are public services that are considered by the whole community and the government because they can coordinate the entire population and awareness of health status. The health care industry must provide high-quality health services because it involves patients. Patients' perceptions of the quality of health services will help medical organizations to increasingly make changes and progress in providing the best services to increase patient satisfaction. Therefore, it is important for the health care industry to continue to improve the quality of services so that the goals of meeting high patient expectations and promoting hospital competitiveness can be achieved. As the demand for improving health services is faced with challenges from various limited resources and intensive competition. Hospitals should be able to prioritize their focus on dimensions that contribute significantly to improving their services.

Quality Function Deployment (QFD) is a tool that can be used to assist companies in the production or service process by translating consumer desires into the company's technical characteristics [1]. QFD was originally proposed in 1966 as an advanced tool for listening to customer voices for continuous product/service quality planning, quality improvement and decision making. Then in Japan, around 1970 QFD technique has proven to be a powerful tool that can be used to translate customer voice into the technical language [2]. Since it was first introduced, QFD is still not popularly applied in healthcare. This is because the initial purpose of implementing QFD is only focused on product development for manufacturing industry.

Cohen (1995) defines QFD as a structured and systematic method for planning and product development that allows the development team to clearly define customer wants and needs. The application of the QFD method in the product design process begins with the formation of a matrix or often referred to as the House Of Quality (HoQ). HoQ displays the voice of the customer (VoC) 
or the customer's need for a technical response to fulfill it. The HoQ sections/rooms each store specific information for a section of the QFD procedure as shown in Figure 1

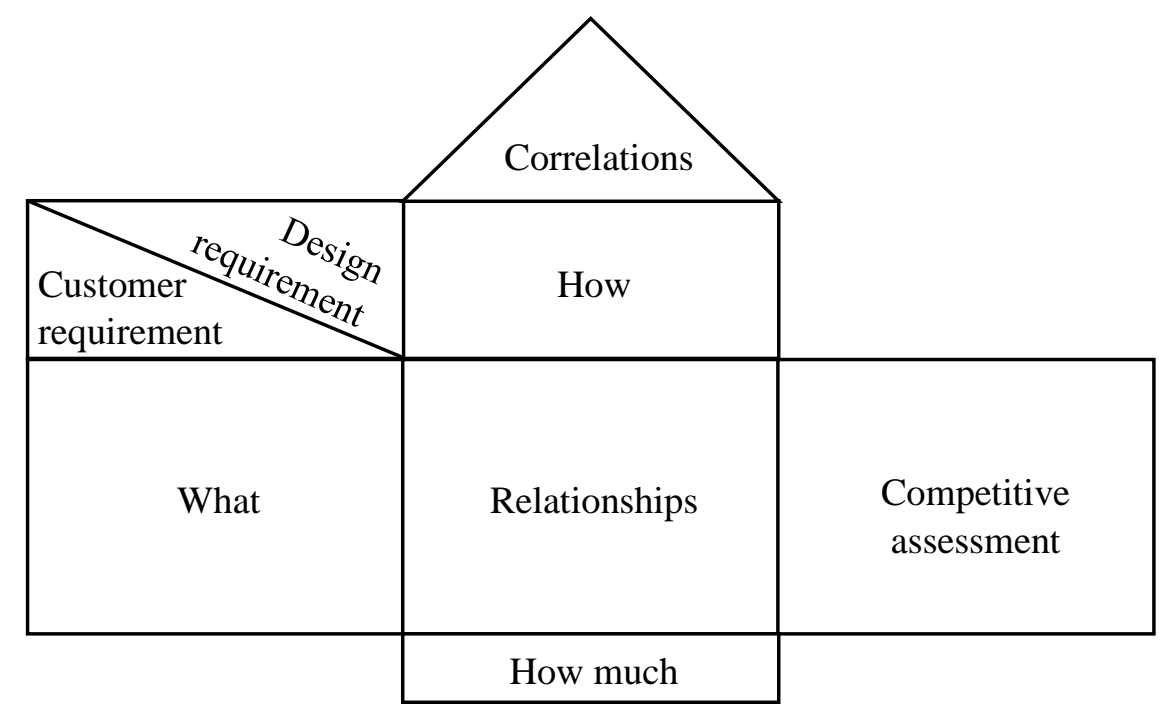

Figure $1 \mathrm{HoQ}$

This paper aims to provide a literature review on the application of QFD in the health care industry and provide contextual knowledge as a means to improve the application of QFD in health services.

\section{Methods}

This This paper presents the best steps to study, explore and analyze the application of QFD in the healthcare industry. This Systematic Literature Review (SLR) study begins with determining the topic, namely the application of QFD in the health care industry. Then proceed to the systematic stage of SLR. The following is an explanation of each stage:

- The first step: Submission of Papers.

Search Papers from famous databases like Research Gate, Google Scholar. Search papers using the keyword "Quality Function Deployment". The collected papers were 138 papers.

- Second step: Screening Papers by topic.

The papers that have been collected are then filtered based on the chosen topic, namely QFD Implementation in the health care sector. Filter papers into 60 papers according to relevant topics. Paper screening is done based on title and abstract.

- Third step: Screening papers by content:

After the paper is selected based on the topic, then it is filtered again based on the content analysis of the full text. This analysis includes research focus, purpose, findings, implications. 
- Fourth step: Summary of papers.

After obtaining the final 40 papers, then summarizing all relevant papers based on the identity of the paper and research results. Grouping all papers into several aspects, namely papers based on the area of publication, papers based on the year of publication and grouping papers based on publishers.

- Fifth step: Benefit analysis

Analyze the benefits obtained from each paper. Analyzing research gaps to be developed in further research.

The stages of the Systematic Literature Review in this study can be seen in Figure 2.

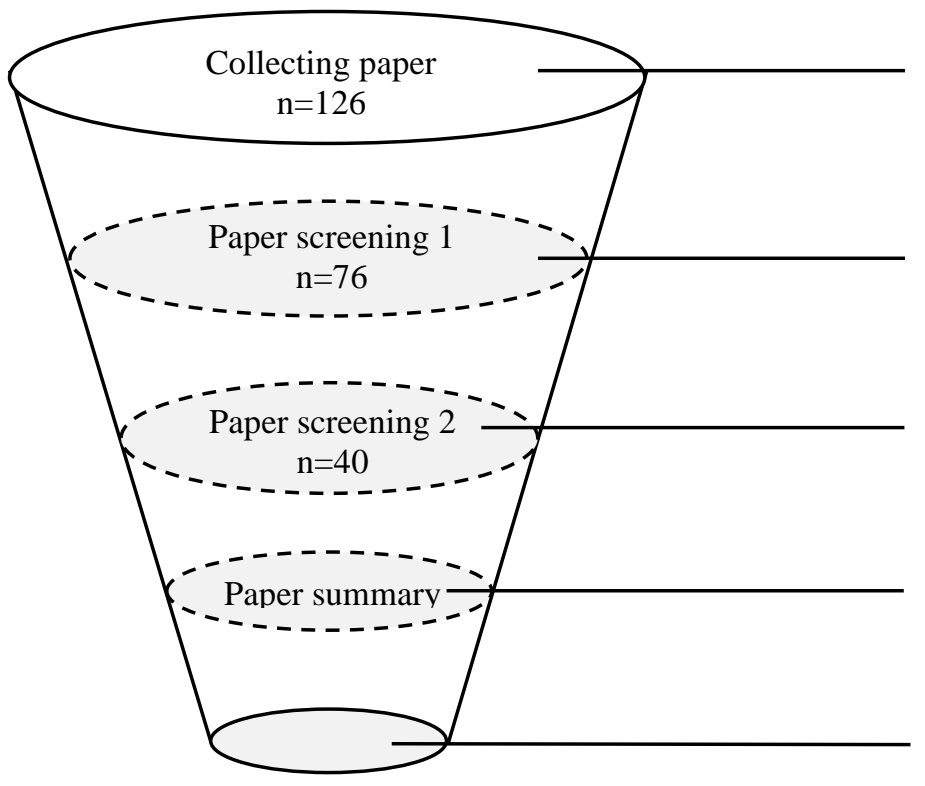

Search papers from the database: Research Gate, Google Scholar

Screening of papers by topics:

- Title and abstract

- Relevance of the topic

Screening of papers by content:

- Fulltext screening

- Research focus

- Purpose, finding and implication

Paper summary

- Paper identity, result

- Country, year, publisher, integration method

Gaps analysis and suggestion for future research

Figure 2 Literature Review Framework

\section{Result and Discussion}

\subsection{Paper Summary}

A total of 40 selected papers will be reviewed in more detail by extracting each paper to obtain the contents of the paper. Then the selected papers are summarized based on the identity of the paper and findings. The following descriptions of each paper can be seen in Table 1

Table 1 An existing literature review of Quality Function Deployment

\begin{tabular}{cll}
\hline No & \multicolumn{1}{c}{ Paper Identity } & \multicolumn{1}{c}{ Findings } \\
\hline 1 & $\begin{array}{l}\text { Gupta \& Srivastava } \\
(2011)[4]\end{array}$ & $\begin{array}{l}\text { Help managers to prioritize the importance of service quality } \\
\text { that can increase customer satisfaction in health services. }\end{array}$ \\
\hline 2 & $\begin{array}{l}\text { Al-Bashir et al. (2012) } \\
{[5]}\end{array}$ & $\begin{array}{l}\text { A new model has been proposed to be implemented to improve } \\
\text { MDMS performance. }\end{array}$ \\
\hline 3 & $\begin{array}{l}\text { Venkaeswarlu \& Birru } \\
\text { (2012) [6] }\end{array}$ & Improving the quality of hospital services. \\
\hline
\end{tabular}




\begin{tabular}{|c|c|c|}
\hline No & Paper Identity & Findings \\
\hline 4 & Sharma (2012) [7] & $\begin{array}{l}\text { The results obtained are the Standard Weight and Priority Score } \\
\text { on the CTG function. The machine came out showing functional } \\
\text { limitations during theoretical analysis. }\end{array}$ \\
\hline 5 & Sinha et al. (2013) [8] & $\begin{array}{l}\text { The behavior and attitudes of the staff have the highest weighted } \\
\text { score, meaning that if they are increased, there will be almost a } \\
25 \text { percent increase in the hospital. }\end{array}$ \\
\hline 6 & $\begin{array}{l}\text { Azadi \& Farzipoor } \\
\text { (2013) [9] }\end{array}$ & $\begin{array}{l}\text { The QFD model can incorporate criteria such as cost of service } \\
\text { and ease of implementation. }\end{array}$ \\
\hline 7 & $\begin{array}{l}\text { Shih \& Chen (2013) } \\
{[10]}\end{array}$ & $\begin{array}{l}\text { Engineering characteristics (EC) are a priority in meeting } \\
\text { customer needs. QFD is here to make it happen and has been } \\
\text { proven for product development. }\end{array}$ \\
\hline 8 & $\begin{array}{l}\text { Gremyr \& Raharjo } \\
\text { (2013) [11] }\end{array}$ & $\begin{array}{l}\text { The multi-customer concept that results from implementing } \\
\text { QFD leads to increased awareness that results in complex } \\
\text { outcomes. }\end{array}$ \\
\hline 9 & Yeh \& Lai (2014) [12] & $\begin{array}{l}\text { Top management can apply a V-shaped performance matrix to } \\
\text { determine the importance of improving quality management. }\end{array}$ \\
\hline 10 & $\begin{array}{l}\text { Chowdhury \& Quddus } \\
\text { (2014) [13] }\end{array}$ & $\begin{array}{l}\text { The optimal strategy is the campaign, recruitment of skilled } \\
\text { human resources, performance measurement, and monitoring. }\end{array}$ \\
\hline 11 & Lee et al. (2015)[14] & $\begin{array}{l}\text { The integration of QFD with Fuzzy Logic makes health care } \\
\text { medical practitioners understand customer desires. Another } \\
\text { thing that is obtained makes a reference as a continuous } \\
\text { improvement when providing health services. }\end{array}$ \\
\hline 12 & $\begin{array}{l}\text { Ionica \& Leba (2015) } \\
{[15]}\end{array}$ & $\begin{array}{l}\text { QFD method can be implemented in the innovative product NPD } \\
\text { approach to produce innovative products by achieving customer } \\
\text { satisfaction requirements. }\end{array}$ \\
\hline 13 & Hashemi (2015) [16] & $\begin{array}{l}\text { The QFD used showed that the time spent on prescribing } \\
\text { medication had been reduced by more than } 20 \text { percent. }\end{array}$ \\
\hline 14 & Nordin (2015)[17] & $\begin{array}{l}\text { The satisfaction coefficient is used to formulate optimization } \\
\text { outputs for new and better health services. }\end{array}$ \\
\hline 15 & Sandelands (2015) [18] & $\begin{array}{l}\text { The fuzzy QFD approach can provide a framework for analyzing } \\
\text { technical requirements that can lead to the synthesis of a } \\
\text { customer-oriented system. }\end{array}$ \\
\hline 16 & Wibawa (2016) [19] & $\begin{array}{l}\text { Choose the best priority of improvement measures to increase } \\
\text { user satisfaction. }\end{array}$ \\
\hline 17 & Wood et al. (2016) [20] & $\begin{array}{l}\text { QFD has been applied in the construction industry with a special } \\
\text { focus on supporting green hospital design. }\end{array}$ \\
\hline 18 & $\begin{array}{l}\text { Pormadadkar (2017) } \\
\text { [21] }\end{array}$ & $\begin{array}{l}\text { Prioritization of improvement in treatment for cardiovascular } \\
\text { disease (CVD). }\end{array}$ \\
\hline 19 & $\begin{array}{l}\text { Dehe \& Bamford (2017) } \\
\text { [22] }\end{array}$ & $\begin{array}{l}\text { QFD implementation has resulted in high effectiveness and } \\
\text { efficiency by creating an information platform. QFD also } \\
\text { provides convenience for stakeholders in making decisions so } \\
\text { that maximum results are obtained. }\end{array}$ \\
\hline 20 & $\begin{array}{l}\text { Kassela et al. (2017) } \\
\text { [23] }\end{array}$ & $\begin{array}{l}\text { QFD implementation has provided broad insights, benefits and } \\
\text { challenges to compete. }\end{array}$ \\
\hline 21 & Hsu et al. (2017) [24] & $\begin{array}{l}\text { QFD implementation has provided a significant correlation } \\
\text { between company profitability and social response. }\end{array}$ \\
\hline 22 & $\begin{array}{l}\text { Priyono \& Yulita (2017) } \\
{[25]}\end{array}$ & $\begin{array}{l}\text { The results of the study indicate that the technical requirements } \\
\text { and service attributes are prioritized so that improvements will } \\
\text { be made a priority. }\end{array}$ \\
\hline 23 & $\begin{array}{l}\text { Sachilo et al. (2017) } \\
\text { [26] }\end{array}$ & $\begin{array}{l}\text { QFD provides a systematic approach as a Multi-Stakeholder } \\
\text { policy that captures the voices of stakeholders and aligns them } \\
\text { with policy. }\end{array}$ \\
\hline 24 & Mogol (2018) [27] & Eliminate queues and increase service time. \\
\hline
\end{tabular}




\begin{tabular}{|c|c|c|}
\hline No & Paper Identity & Findings \\
\hline 25 & Raziei et al. (2018) [28] & $\begin{array}{l}\text { QFD and Servqual characteristics can be used to translate patient } \\
\text { requirements into design characteristics and quality. }\end{array}$ \\
\hline 26 & Kim et al. (2018) [29] & Utilizing QFD to develop services on a national scale in Korea. \\
\hline 27 & Ali (2018) [30] & $\begin{array}{l}\text { Availability of data that is very useful for hospital authorities and } \\
\text { health statisticians to track different public health parameters }\end{array}$ \\
\hline 28 & Siregar (2019) [31] & $\begin{array}{l}\text { It was found that } 4 \text { attributes were the main priority for } \\
\text { improvement, including good communication with patients, } \\
\text { preparedness of medical personnel, the competence of medical } \\
\text { personnel, and medical equipment. }\end{array}$ \\
\hline 29 & $\begin{array}{l}\text { Joshi \& Bhargava } \\
\text { (2019) [32] }\end{array}$ & $\begin{array}{l}\text { Green QFD provides knowledge, attitudes and roles of health } \\
\text { practitioners in medical waste management to provide } \\
\text { environmentally friendly services. }\end{array}$ \\
\hline 30 & Barad (2019) [33] & $\begin{array}{l}\text { QFD developed } 2 \text { matrices to improve the strategic health care } \\
\text { system into a need for increasing cyber information. }\end{array}$ \\
\hline 31 & $\begin{array}{l}\text { Hasibuan et al. (2019) } \\
\text { [34] }\end{array}$ & $\begin{array}{l}\text { The implementation of QFD produces } 33 \text { service quality } \\
\text { characteristics as elements that need to be improved. Of these } 33 \\
\text { characteristics, there is one main priority, namely patience for } \\
\text { recovery. }\end{array}$ \\
\hline 32 & Gonzale & $\begin{array}{l}\text { QFD and benchmarking to bridge the gap and assess the extent } \\
\text { to which customers are happy and satisfied with the products and } \\
\text { services provided by the business. }\end{array}$ \\
\hline 33 & Barutcu (2019) [36] & Designing the mHealth app for a higher level of satisfaction \\
\hline 34 & $\begin{array}{l}\text { Kayapinar \& Erginel } \\
(2020)[37]\end{array}$ & $\begin{array}{l}\text { Quality Function Deployment used to prioritize patient needs } \\
\text { and patient expectations. }\end{array}$ \\
\hline 35 & $\begin{array}{l}\text { Putra \& Wang (2020) } \\
{[38]}\end{array}$ & $\begin{array}{l}\text { With QFD, it can be seen that there is a strong relationship } \\
\text { between doctors' skills, behavior and attitudes of officers, as well } \\
\text { as having quite modern equipment. }\end{array}$ \\
\hline 36 & Cropley (2020) [39] & $\begin{array}{l}\text { QFD combined with Value Engineering creates innovative } \\
\text { methods and results in a quality function of maximizing results } \\
\text { and becomes a model for customer satisfaction in the field of } \\
\text { cost management. }\end{array}$ \\
\hline 37 & (Nie et al. (2020) [40] & $\begin{array}{l}\text { Improving the quality of health services with QFD and Todim to } \\
\text { ensure quality improvement by the psychological behavior of the } \\
\text { patient who provides the assessment. }\end{array}$ \\
\hline 38 & $\begin{array}{l}\text { Mathews et al. (2020) } \\
\text { [41] }\end{array}$ & $\begin{array}{l}\text { Application of integrated quality functions and failure modes } \\
\text { and analysis of effects in the selection of subcontractors for the } \\
\text { ISO/IEC } 17025 \text { Standard }\end{array}$ \\
\hline 39 & Duan et al. (2020) [42] & $\begin{array}{l}\text { Application of QFD with fuzzy mechanism analyzes washing } \\
\text { machine quality accidents. }\end{array}$ \\
\hline 40 & gi (2020) [43] & $\begin{array}{l}\text { Increase customer satisfaction which has an impact on } \\
\text { increasing profits. }\end{array}$ \\
\hline
\end{tabular}

Based on Table 1, it can be seen that this paper summarizes as many as 40 papers related to the application of QFD in the health care industry. Based on the summary, then grouping into several aspects such as year of publication, country of publication, integration method and publisher. The following is a description of each based on the grouping of papers

\subsection{Classification of Papers}

This paper identifies based on the aspects reviewed. The identified papers were traced from publications from 2011 to 2020 (Figure 3). The analysis found that the application of QFD is still relatively new because the development of this tool is reviewed based on the selection of papers in the last 10 years. QFD is considered an innovation in improving the service quality. So this 
method needs to be developed again. The success of QFD in the healthcare industry has brought significant benefits to the industry sector. Then the QFD method becomes the main target for the service industry, especially health services.

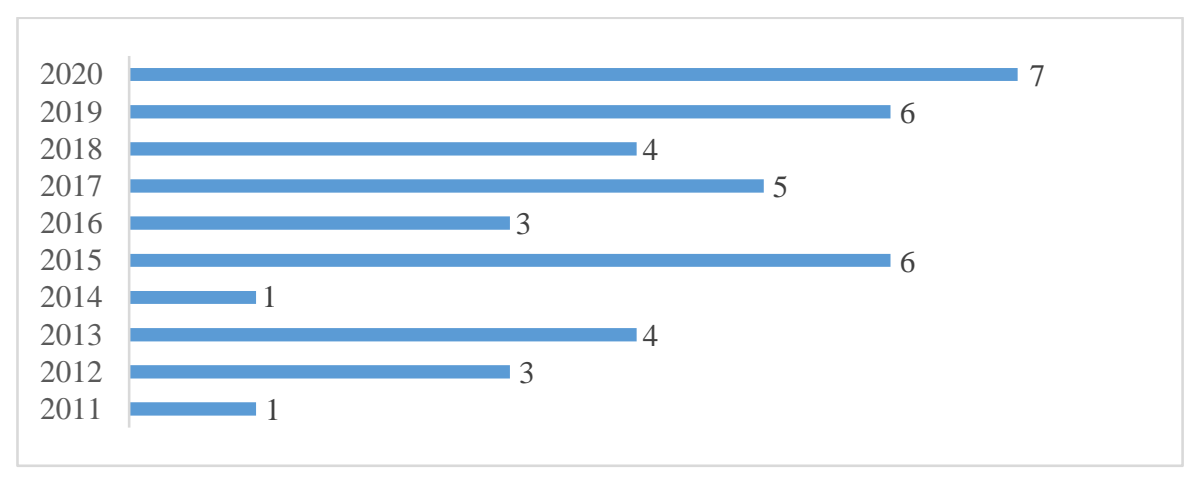

Figure 3 Papers by year

Based on a thorough identification, as many as 10 papers have used the QFD method as the main method in improving the service quality. This shows that the QFD method is a single method that can provide significant changes when applied. In addition, QFD is also a method for product/service development. QFD itself can provide recommendations for the right model in developing products/services. When applied to an industry or research, QFD is often integrated with various methods of improvement, weighting and decision making to obtain complex results. Based on the analysis, the integration method includes the AHP method to analyze or support decision-making. The fuzzy method can model very complex nonlinear functions so that it can build and apply experiences directly. Data Envelopment Analysis (DEA) method as a tool to measure efficiency criteria. Kano's method can lead to the development of broad service differentiation by analyzing customer attributes. The integration of the QFD method with several other methods can be seen in Figure 4.

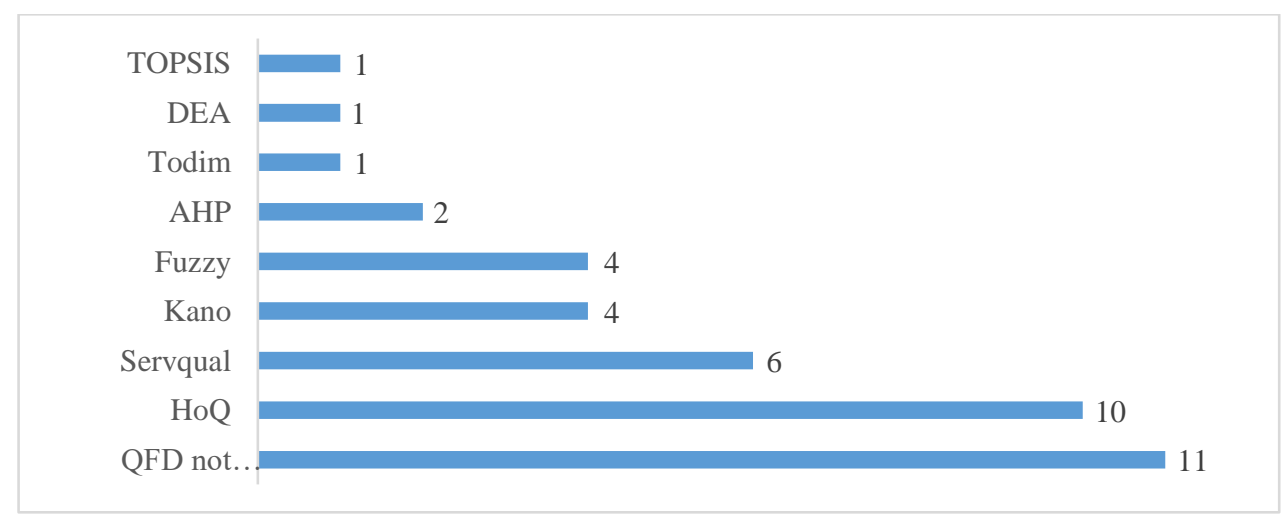

Figure 4 Integration method

This paper also identifies the distribution of publications by country and publisher. The analysis found that Iran is the largest supplier of publications with 5 papers. Then Elsevier became the most recommended publisher in this literature study. Information about the distribution of papers and where the papers are published can be seen in Figure 5 and Figure 6. 


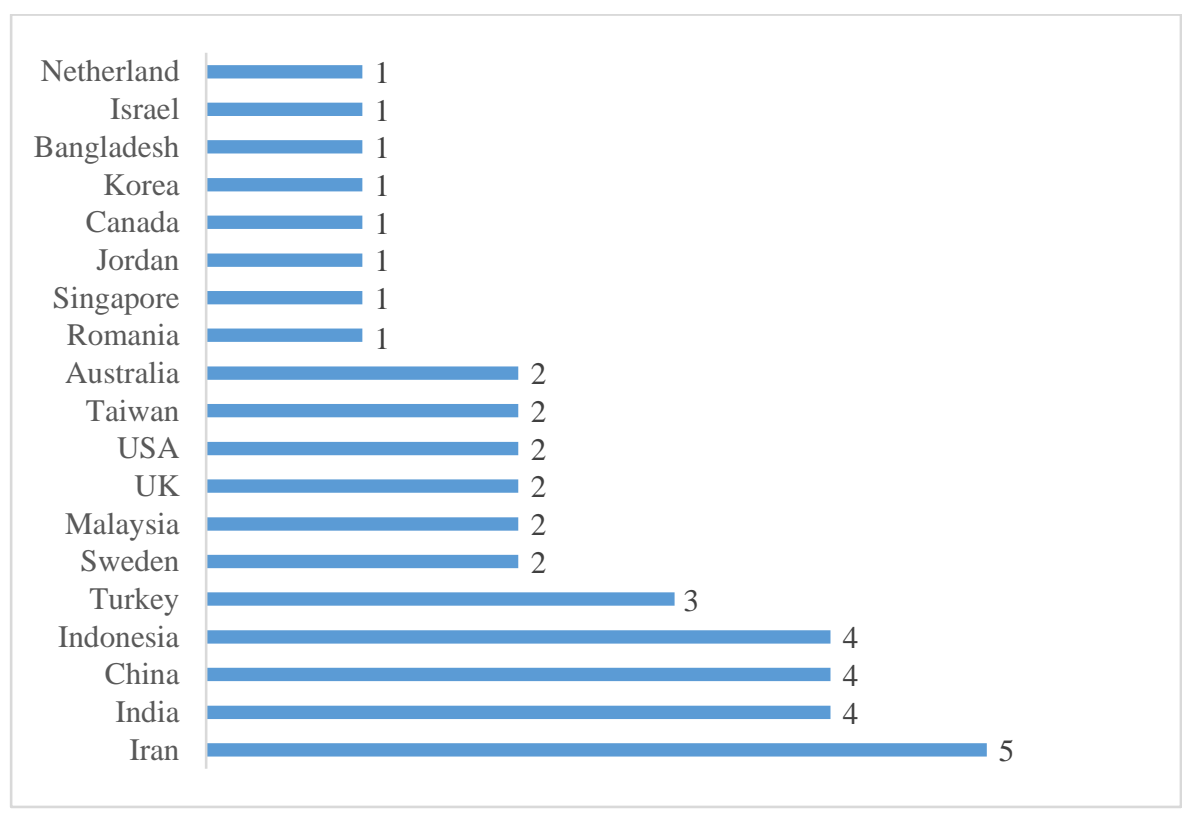

Figure 5 Papers by region

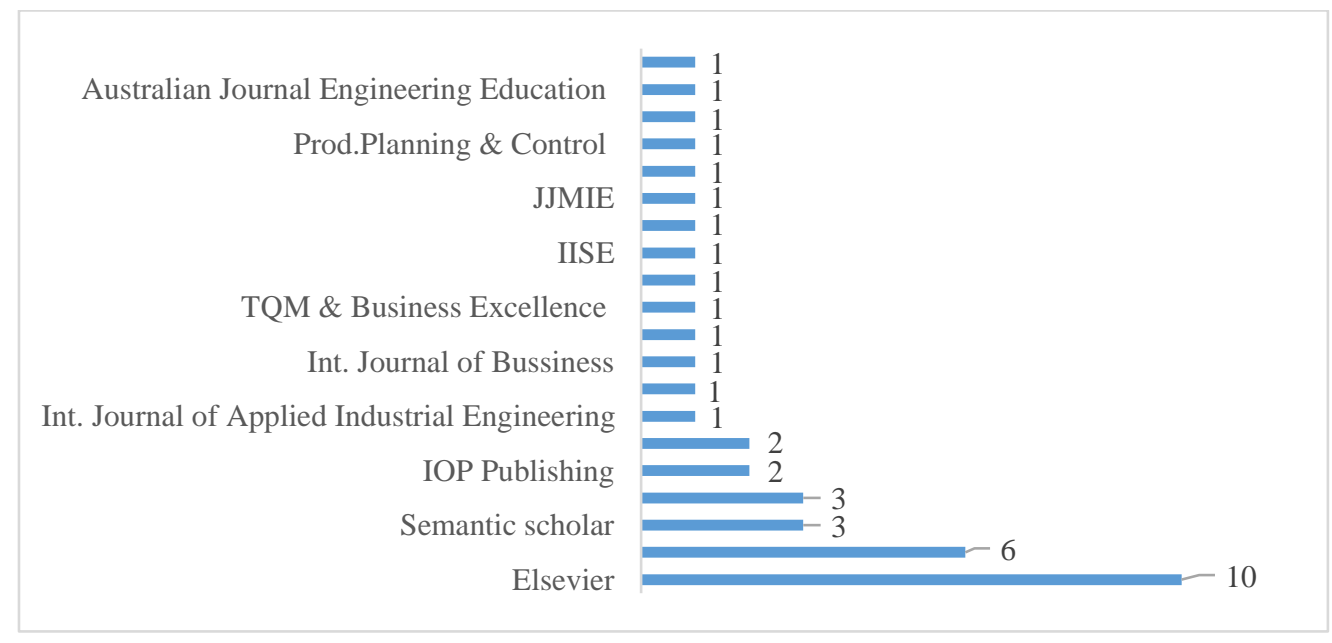

Figure 6 Papers by publisher

\subsection{QFD Implementation Benefits}

The presence of QFD as an improvement method brings significant advantages to the healthcare industry. This is because QFD can be the basis of activities to translate customer desires. This paper has analyzed the advantages that the healthcare industry gets when implementing QFD. QFD can increase competitiveness through continuous improvement of its quality and productivity. Broadly speaking, the benefits of QFD are as follows:

1. Focus on the customer.

2. Time efficiency.

3. Teamwork-oriented.

4. Orientation to documentation. 


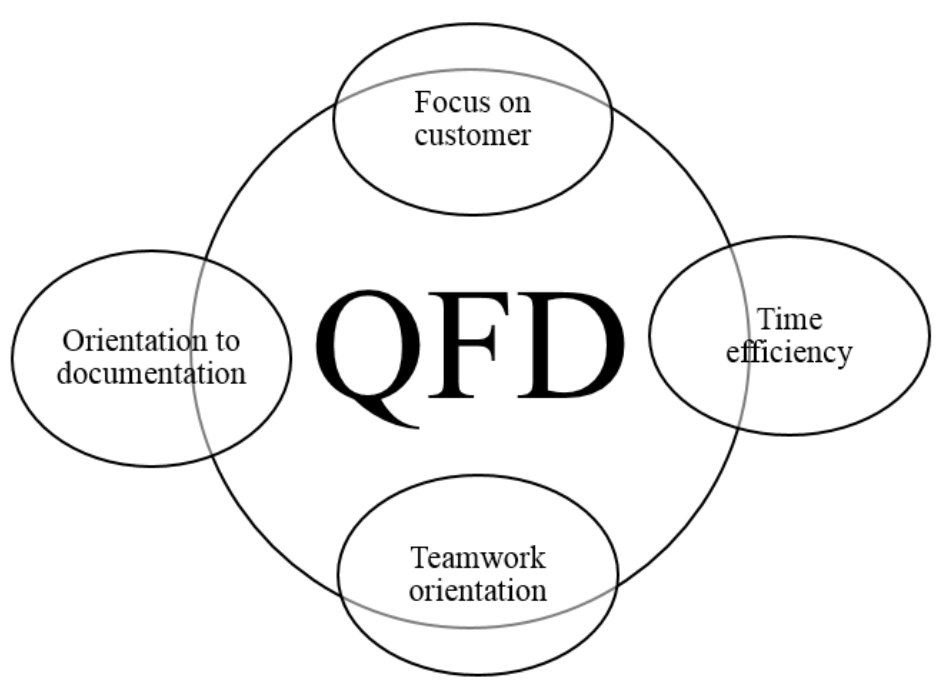

Figure 7 Benefits of QFD

Based on the four benefits of QFD in Figure 7, we can see that specifically the benefits of implementing QFD in the health care industry are increasing product reliability, improving service quality, increasing customer satisfaction, shortening time to market, reducing design costs, improving communication, increasing productivity and increase company profits. This QFD method also has weaknesses, including requiring specific skills when translating quality characteristics, difficulties in filling out the matrix and being a project without continuation.

\subsection{Gaps and Future Research}

QFD is a method used to support and implement the philosophy of Total Quality Management (TQM). Quality is paramount to all industries. By focusing on improving quality, customers will feel satisfied. This will have an impact on company profits. In future research, it is recommended to focus more on the application of QFD based on TQM. QFD itself consists of three stages. All activities carried out at each stage can be applied like a project, with the planning and preparation stages first. The three stages are (1) Voice of Customer collection stage; (2) the stage of compiling a house of quality (House of Quality); (3) Analysis and implementation stage. Each stage of the implementation of QFD requires special attention to obtain complex and reliable results.

\section{Conclusion}

Since it was first introduced QFD is still not popularly used in healthcare. So, this paper aims to provide a broad understanding and knowledge of the application of QFD in the healthcare. QFD is an approach that can help companies improve services by translating consumer desires into the company's technical characteristics. Based on the analyzed literature, the main focus of QFD as a approach used to improve services so the service industry need to implement it, especially health services. QFD can produce output by the tastes and desires of consumers. QFD has developed into a powerful tool to improve service quality that focuses on customer needs. Through HoQ the implementation of QFD becomes more structured and valuable so that the expected goals will be achieved. Future research is suggested to apply QFD with the TQM foundation. 


\section{REFERENCES}

[1] Narto, "Integrasi Metode Swot dan QFD Untuk Meningkatan Daya Saing Usaha Melalui Pengembangan Produk Otak-Otak Bandeng Gresik," Spektrum Ind., vol. 18, no. 1, pp. 65-74, 2020, doi: http://dx.doi.org/10.12928/si.v18i1.13990.

[2] A. Z. Yamani and A. Munang, "Rancang Bangun Alat Panjat Untuk Penderes Nira Kelapa Di Kabupaten Banyumas," Spektrum Ind., vol. 17, no. 1, p. 87, 2019, doi: 10.12928/si.v17i1.12727.

[3] Cohen, Quality Fuction Deployment: How to Make QFD Work for You. Massachusetts: Addison Wesley Publishing Co., 1995.

[4] P. Gupta and R. K. Srivastava, "Customer Satisfaction for Designing Attractive Qualities of Healthcare Service in India using Kano,” MIT Int. J. Mech. Eng., vol. 1, no. 2, pp. 101-107, 2011.

[5] A. Al-Bashir, M. Al-Rawashdeh, R. Al-Hadithi, A. Al-Ghandoor, and M. Barghash, "Building medical devices maintenance system through quality function deployment," Jordan J. Mech. Ind. Eng., vol. 6, no. 1, pp. 25-36, 2012.

[6] C. Venkateswarlu and A. K. Birru, "Integrated Quality Function Deployment as a Tool for Quality Achievement in Healthcare,” Int. J. Appl. Ind. Eng., vol. 1, no. 2, pp. 80-92, 2012, doi: 10.4018/ijaie.2012070106.

[7] J. Sharma, "Optimised design and development of a bio-medical healthcare device through quality function deployment (QFD).," Int. J. Electron. Healthc., vol. 7, no. 1, pp. 68-87, 2012, doi: 10.1504/IJEH.2012.048670.

[8] M. Sinha, H. Camgöz $\square$ Akdağ, M. Tarım, S. Lonial, and A. Yatkın, "QFD application using SERVQUAL for private hospitals: a case study," Leadersh. Heal. Serv., vol. 26, no. 3, pp. 175-183, Jul. 2013, doi: 10.1108/LHS-02-2013-0007.

[9] M. Azadi and R. Farzipoor Saen, "A combination of QFD and imprecise DEA with enhanced Russell graph measure: A case study in healthcare," Socioecon. Plann. Sci., vol. 47, no. 4, pp. 281-291, 2013, doi: 10.1016/j.seps.2013.05.001.

[10] H.-S. Shih and S.-H. Chen, "A Conceptual Design of a Mobile Healthcare Device - An Application of Three-Stage QFD with ANP and TRIZ,” Int. J. Oper. Res., vol. 10, no. 2, pp. 80-91, 2013, doi: 10.13033/isahp.y2013.001.

[11] I. Gremyr and H. Raharjo, "Quality function deployment in healthcare: A literature review and case study,” Int. J. Health Care Qual. Assur., vol. 26, no. 2, pp. 135-146, 2013, doi: 10.1108/09526861311297343. 
[12] T. Yeh and H. . Lai, "Evaluating the effectiveness of implementing quality management practices in the medical industry," Springer, vol. 19, no. October, pp. 102-112, 2015, doi: https://doi.org/10.1007/s12603-014-0486-4.

[13] M. M. H. Chowdhury and M. A. Quaddus, "A multi-phased QFD based optimization approach to sustainable service design,” Int. J. Prod. Econ., vol. 171, pp. 165-178, 2014, doi: 10.1016/j.ijpe.2015.09.023.

[14] C. K. M. Lee, C. T. Y. Ru, C. L. Yeung, K. L. Choy, and W. H. Ip, "Analyze the healthcare service requirement using fuzzy QFD,” Comput. Ind., vol. 74, pp. 1-15, 2015, doi: 10.1016/j.compind.2015.08.005.

[15] A. C. Ionica and M. Leba, "QFD Integrated in New Product Development - Biometric Identification System Case Study," Procedia Econ. Financ., vol. 23, no. October 2014, pp. 986-991, 2015, doi: 10.1016/s2212-5671(15)00454-2.

[16] N. Hashemi, M. Marzban, and S. Delavari, "Quality function deployment: Application to chemotherapy unit services,” Middle East J. Cancer, vol. 6, no. 4, pp. 219-228, 2015.

[17] N. Nordin, "A Conceptual Kano and Quality Function Deployment ( QFD ) Framework For Healthcare,” Conf. 2nd Int. Conf. Roles Humanit. Soc. Sci. Eng. 2010 (ICoHSE 2), no. November, 2015.

[18] E. Sandelands, "Combined quality function deployment and the logical framework approach to improve quality of emergency care in Malta," Int. J. Health Care Qual. Assur., vol. 7, no. 4, pp. 1-40, 2015, doi: 10.1108/09526862199400001.

[19] J. Wibawa, Meyliana, H. A. E. Widjaja, and A. N. Hidayanto, "Integrating IS Success Model, SERVQUAL and Kano Model into QFD to improve Hospital Information System quality,” Proc. 2016 Int. Conf. Inf. Manag. Technol. ICIMTech 2016, no. November, pp. 29-34, 2016, doi: 10.1109/ICIMTech.2016.7930297.

[20] L. C. Wood, C. Wang, H. Abdul-Rahman, and N. S. Jamal Abdul-Nasir, "Green hospital design: Integrating quality function deployment and end-user demands," J. Clean. Prod., vol. 112, pp. 903-913, 2016, doi: 10.1016/j.jclepro.2015.08.101.

[21] M. Pourmadadkar, M. A. Beheshtinia, and K. Ghods, "An integrated approach for healthcare services risk assessment and quality enhancement," Int. J. Qual. Reliab. Manag., vol. 37, no. 9-10, pp. 1183-1208, 2017, doi: 10.1108/IJQRM-11-2018-0314.

[22] B. Dehe and D. Bamford, "Quality Function Deployment and operational design decisions-a healthcare infrastructure development case study," Prod. Plan. Control, vol. 28, no. 14, pp. 1177-1192, 2017, doi: 10.1080/09537287.2017.1350767. 
[23] K. Kassela, M. Papalexi, and D. Bamford, "Applying quality function deployment to social housing?,” TQM J., vol. 29, no. 3, pp. 422-436, 2017, doi: 10.1108/TQM-03-20160030 .

[24] C. H. Hsu, A. Y. Chang, and W. Luo, "Identifying key performance factors for sustainability development of SMEs - integrating QFD and fuzzy MADM methods," J. Clean. Prod., vol. 161, pp. 629-645, 2017, doi: 10.1016/j.jclepro.2017.05.063.

[25] A. Priyono and A. Yulita, "Integrating Kano Model and Quality Function Deployment for designing service in hospital front office,” Intang. Cap., vol. 13, no. 5, pp. 923-945, 2017, doi: 10.3926/ic.1001.

[26] R. S. Schillo, D. A. Isabelle, and A. Shakiba, "Linking advanced biofuels policies with stakeholder interests: A method building on Quality Function Deployment," Energy Policy J., vol. 100, no. October 2016, pp. 126-137, 2017, doi: http://dx.doi.org/10.1016/j.enpol.2016.09.056.

[27] M. Moğol Sever, "Improving check-in (C/I) process: an application of the quality function deployment," Int. J. Qual. Reliab. Manag., vol. 35, no. 9, pp. 1907-1919, Oct. 2018, doi: 10.1108/IJQRM-03-2017-0043.

[28] Z. Raziei, S. A. Torabi, S. Tabrizian, and B. Zahiri, "A Hybrid GDM-SERVQUAL-QFD Approach for Service Quality Assessment in Hospitals,” EMJ - Eng. Manag. J., vol. 30, no. 3, pp. 179-190, 2018, doi: 10.1080/10429247.2018.1443670.

[29] K. J. Kim et al., "Development of service concepts that utilize health-related data: A case study with the National Health Insurance Service of South Korea," IISE Trans. Healthc. Syst. Eng., vol. 8, no. 4, pp. 237-249, 2018, doi: 10.1080/24725579.2018.1502221.

[30] M. Ali Akram, M. Iqbal Mahmud, S. Riad Bin Ashraf, S. Awal, and S. Talapatra, "Enhancing the Healthcare Service Using Quality Function Deployment and Database Management System in the Outpatient Department of a Government Hospital of Bangladesh,” Int. Res. J. Eng. Technol., vol. 5, no. 4, pp. 2022-2029, 2018.

[31] I. Siregar, "Application Quality Function Deployment to Improve Quality of Patient Service in Hemodialysis Installation,” IOP Conf. Ser. Mater. Sci. Eng., vol. 598, no. 1, pp. 0-4, 2019, doi: 10.1088/1757-899X/598/1/012038.

[32] S. Joshi and P. Bhargava, "Waste Management Integration with Green Quality Function Deployment (G-QFD) for Healthcare Centre," Prod. Eng. Arch., vol. 22, no. 22, pp. 4549, 2019, doi: 10.30657/pea.2019.22.09. 
[33] M. Barad, "Linking cyber security improvement actions in healthcare systems to their strategic improvement needs," Procedia Manuf., vol. 39, pp. 279-286, 2019, doi: 10.1016/j.promfg.2020.01.335.

[34] A. Hasibuan et al., "Service Quality Improvement by Using the Quality Function Deployment (QFD) Method at the Government General Hospital," J. Phys. Conf. Ser., vol. 1363, no. 1, 2019, doi: 10.1088/1742-6596/1363/1/012095.

[35] M. E. Gonzalez, "Improving customer satisfaction of a healthcare facility: reading the customers' needs," Benchmarking, vol. 26, no. 3, pp. 854-870, 2019, doi: 10.1108/BIJ01-2017-0007.

[36] S. Barutçu, "mHealth apps design using quality function deployment," Int. J. Health Care Qual. Assur., vol. 32, no. 4, pp. 698-708, 2019, doi: 10.1108/IJHCQA-08-2018-0195.

[37] S. Kayapinar Kaya and N. Erginel, "Futuristic airport: A sustainable airport design by integrating hesitant fuzzy SWARA and hesitant fuzzy sustainable quality function deployment,” J. Clean. Prod., vol. 275, 2020, doi: 10.1016/j.jclepro.2020.123880.

[38] N. U. Putra and F. K. Wang, "Integrating quality function deployment and failure mode and effect analysis in subcontractor selection,” Total Qual. Manag. Bus. Excell., vol. 31, no. 7-8, pp. 697-716, 2020, doi: 10.1080/14783363.2018.1444473.

[39] D. H. Cropley, "Applying quality function deployment to the design of engineering programmes: approaches, insights and benefits,” Australas. J. Eng. Educ., vol. 00, no. 00, pp. 1-14, 2020, doi: 10.1080/22054952.2020.1776532.

[40] R. xin Nie, Z. peng Tian, C. Kwai Sang, and J. qiang Wang, "Implementing healthcare service quality enhancement using a cloud-support QFD model integrated with TODIM method and linguistic distribution assessments," J. Oper. Res. Soc., vol. 0, no. 0, pp. 123, 2020, doi: 10.1080/01605682.2020.1824554.

[41] S. C. Mathews et al., "Prioritizing Health Care Solutions for Pressure Ulcers Using the Quality Function Deployment Process,” Am. J. Med. Qual., vol. 35, no. 3, pp. 197-204, 2020, doi: 10.1177/1062860619869990.

[42] P. Duan, Z. He, Y. He, F. Liu, A. Zhang, and D. Zhou, "Root cause analysis approach based on reverse cascading decomposition in QFD and fuzzy weight ARM for quality accidents," Comput. Ind. Eng., vol. 147, 2020, doi: 10.1016/j.cie.2020.106643.

[43] K. Yeganegi, "The integration of QFD Technique and Value Engineering and its Applying in a Healthcare Center," SSRN Electron. J., pp. 650-659, 2020, doi: 10.2139/ssrn.3601792. 